\title{
Impact of CSO Manage Training Programs on Individual and Organizational Performance
}

\author{
Agus Yuniawan Isyanto*1 Tjahjo Suprajogo $^{2} \quad$ Adiyati Fathu Roshonah $^{3} \quad$ Diah Andika Sari $^{3}$ \\ 1.Universitas Galuh, Indonesia \\ 2.Institut Pemerintahan Dalam Negeri, Indonesia \\ 3.Universitas Muhammadiyah Jakarta, Indonesia
}

\begin{abstract}
Human resource problems faced by CSOs are the limited number of employees compared to organizational activities, low employee skills, and lack of employee experience in managing the activities of the organization. Based on these problems, NICE Indonesia conducted a CSO Manage training program which was participated by 10 CSOs. This research was conducted with the aim of evaluating the CSO Manage training program. 10 CSO participants in the CSO Manage training program were taken entirely as research samples. Evaluation of the CSO Manage training program is carried out using the Kirkpatrick four-level evaluation model. The results showed that the objectives of the CSO Manage training program could be achieved as indicated by an increase in knowledge and changes in participant behavior, as well as an increase in individual and organizational performance.
\end{abstract}

Keywords: Training, CSO Manage, NICE Indonesia, Kirkpatrick Four-Level Evaluation Model

DOI: $10.7176 / \mathrm{EJBM} / 12-2-05$

Publication date: January $31^{\text {st }} 2020$

\section{Introduction}

The formation of civil society organizations (CSOs) is a form of community participation in efforts to improve the living standards and welfare of the community independently. The effectiveness of an organization is strongly influenced by the quality of its resources (Herdiansah and Randi, 2016).

CSOs must focus on building the capacity of the organization's resources if they want to maximize the social impact of their existence, but they are difficult to build organizational capacity to support the development and dissemination of programs caused by the human resources they have. Human resource problems faced by CSOs are the limited number of employees compared to organizational activities, low employee skills, and lack of employee experience in managing the activities of the organization.

Changes in internal and external environmental conditions must be anticipated by improving the quality of human resources in order to continue to have a competitive advantage (Fita, 2017). Human resources are a key element that can explain why some organizations perform well and some perform poorly (Al-Abbadi et al, 2019). The human management function is an important function in an organization without ignoring other functions (Shehadeh, 2015).

Human resources are an important factor of organizations (Okioga, 2013) in achieving competitive advantage (Pirzada et al, 2013). Human resources are an important factor for achieving the vision and mission of an organization (Walukow et al, 2016), and differentiate the organization from other organizations (Al-Nawaiseh, 2014). One way to develop human resource performance is to hold a training program that is tailored to the needs (Triasmoko et al, 2014). Training is a planned effort designed in an effort to facilitate relevant skills, knowledge and attitudes by members of the organization (Ritonga et al, 2019). Three important things need to be considered in relation to the training program, namely the purpose of the training program, the strategy used in implementing the training program, and the evaluation of the training program (Aryanti et al, 2015).

\section{Research Methodology}

The study was conducted using a qualitative research approach to evaluate the CSO Manage training program implemented by NICE Indonesia. The study was conducted in October-December 2019. The data used in the form of primary data obtained through questionnaires. The CSO Manage training program was held in October and was followed by 10 CSOs, all of which were taken as research samples. Evaluation of the CSO Manage training program is carried out using the Kirkpatrick four-level evaluation model.

\section{Results and Discussions}

The Kirkpatrick evaluation model consists of 4 levels, where each level in this evaluation model influences the next level. The four evaluation levels are: Level 1 (Reaction), which is an evaluation that measures how participants react to a training program, Level 2 (Learning), which is an evaluation that measures the learning process in training namely the transfer of knowledge, Level 3 (Behavior), which is an evaluation which aims to find out the extent to which behavior changes occur after participants have participated in training, and Level 4 (Results), which is an evaluation to measure the final results that occur after participants have participated in 
training (Iskandar, 2019).

\subsection{Level 1 Evaluation (Reaction)}

Evaluation at level 1 is conducted to determine the satisfaction of the training program participants with the performance of the training organizers and instructors. According to Palupi et al (2017), participant satisfaction will increase participants' motivation to attend training programs.

Level 1 evaluation covers the suitability of the training with the needs and expectations of the participants, training place, food served, training equipment, and committee services. Level 1 evaluation results are presented in Figure 1.

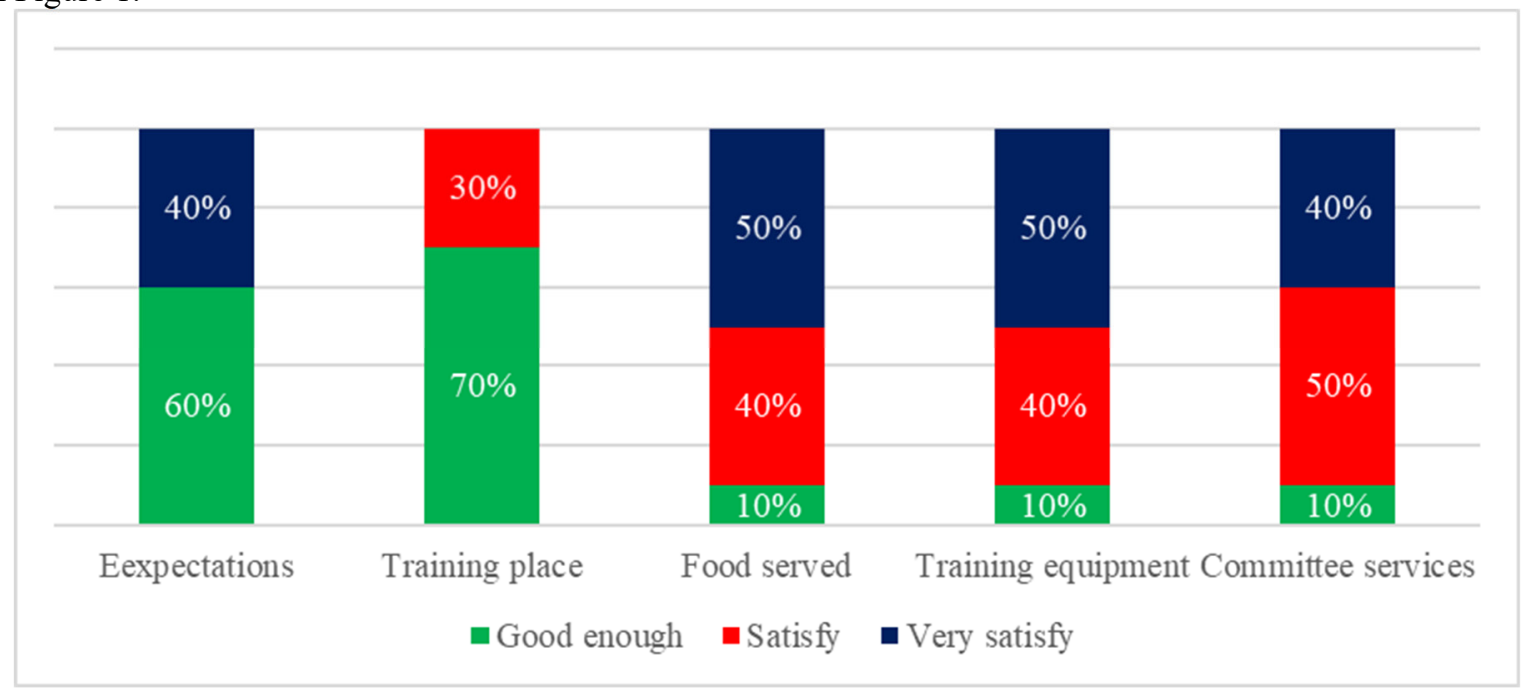

Figure 1. Evaluation of Level 1 (Reaction) of the Committee

Table 1 shows that the participants $(60 \%)$ stated that they were quite satisfied with the training material that suited their needs and expectations. Participants (60\%) also felt quite satisfied with the training venue. Participants' satisfaction with the food served, training equipment and the services of the organizing committee varied from satisfied to very satisfied.

The success of the training program is influenced by the competency of the instructors (Ferdhinawan et al, 2015) which will influence the training program participants in obtaining maximum learning outcomes (Saputri et al, 2019). Evaluation of training instructors includes instructor performance, how instructors explain training material, and how instructors facilitate participant activities. The instructor evaluation results are presented in Figure 2 .

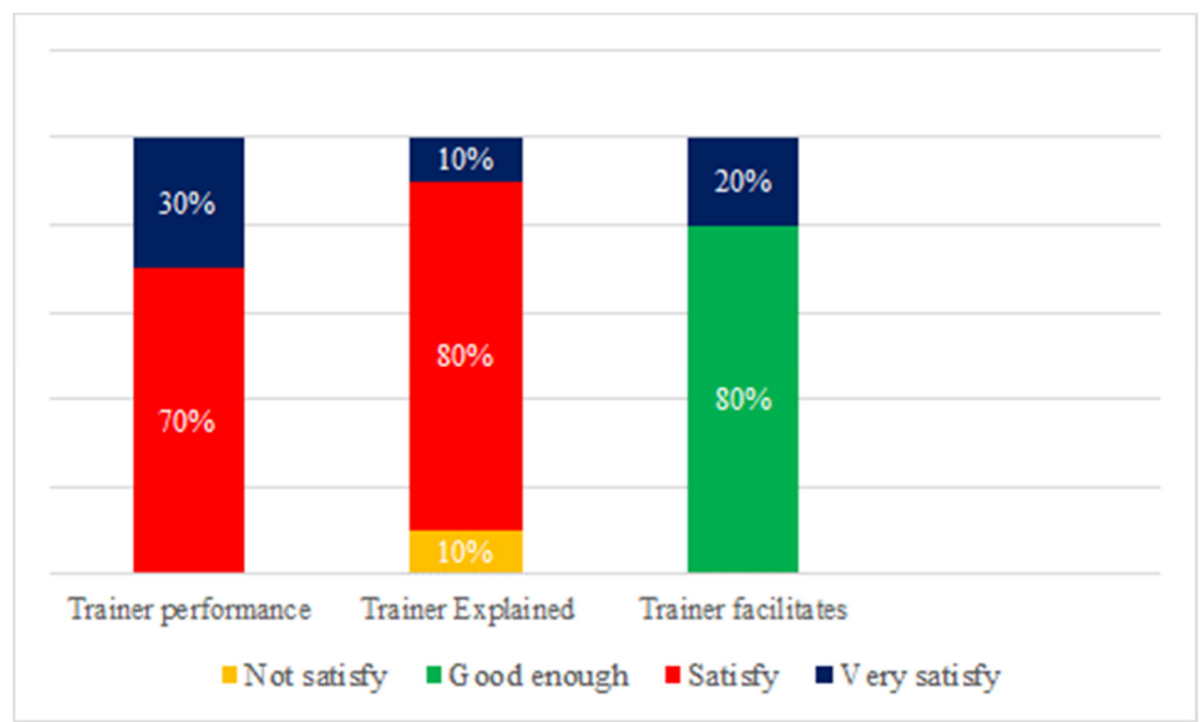

Figure 2. Evaluation of Level 1 (Reaction) of Instructors

Figure 2 shows that participants $(70 \%)$ expressed satisfaction with the instructor's performance, and participants $(80 \%)$ also expressed satisfaction with the way the instructor explained the training material so that they could understand the material presented properly. Participants $(80 \%)$ expressed quite satisfied with the 
instructor in serving the participant's activities.

The satisfaction of the participants with the organizing committee and the instructor of the training program can increase the motivation of the participants in participating in the training program where participants actively participate in each training session.

\subsection{Level 2 Evaluation (Learning)}

Level 2 evaluation (learning) includes evaluating the increase in participant's knowledge after attending the training program, increasing participant's understanding of change management, increasing participant's understanding of organizational strategic issues, and increasing participant's understanding of the function of change agents in the organization. Level 2 (learning) evaluation results are presented in Figure 3.

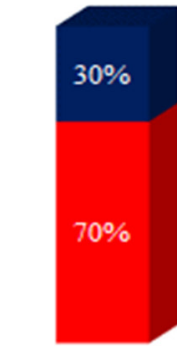

Knowledge

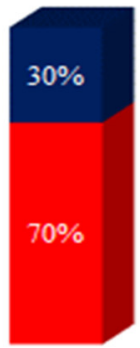

Understanding change managem ent

- Agree

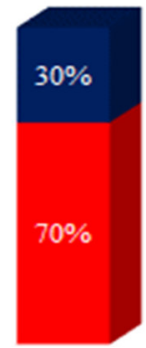

Understanding of strategic issues

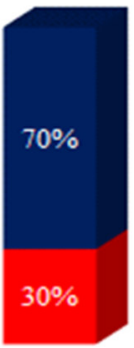

Understanding the functions of change agents

Figure 3. Evaluation of Level 2 (Learning)

Figure 3 shows that participants $(70 \%)$ agreed that the training program could increase their knowledge. Participants also agreed (70\%) that training programs can improve their understanding of change management and organizational strategic issues. Participants $(70 \%)$ quite agree that the training program can improve their understanding of the functions of change agents in the organization.

Level 2 evaluation (learning) shows that the objectives of the training program can be achieved where participants can be increased in knowledge and understanding in accordance with the training material delivered so that it will be a useful provision for participants after they finish training and return to their organizations

\subsection{Level 3 Evaluation (Behavior)}

Level 3 (behavior) evaluation includes evaluating behavioral change in cooperating with others cooperatively, changing behavior more actively in socializing changes made by the organization, changing behavior in motivating colleagues to make better changes, changing behavior to more consistently act in accordance with organizational values and policies, increased creativity in carrying out tasks in the organization, increased discipline of participants in the organization, and increased responsibility in carrying out tasks in the organization. Level 3 (behavior) evaluation results are presented in Figure 4.

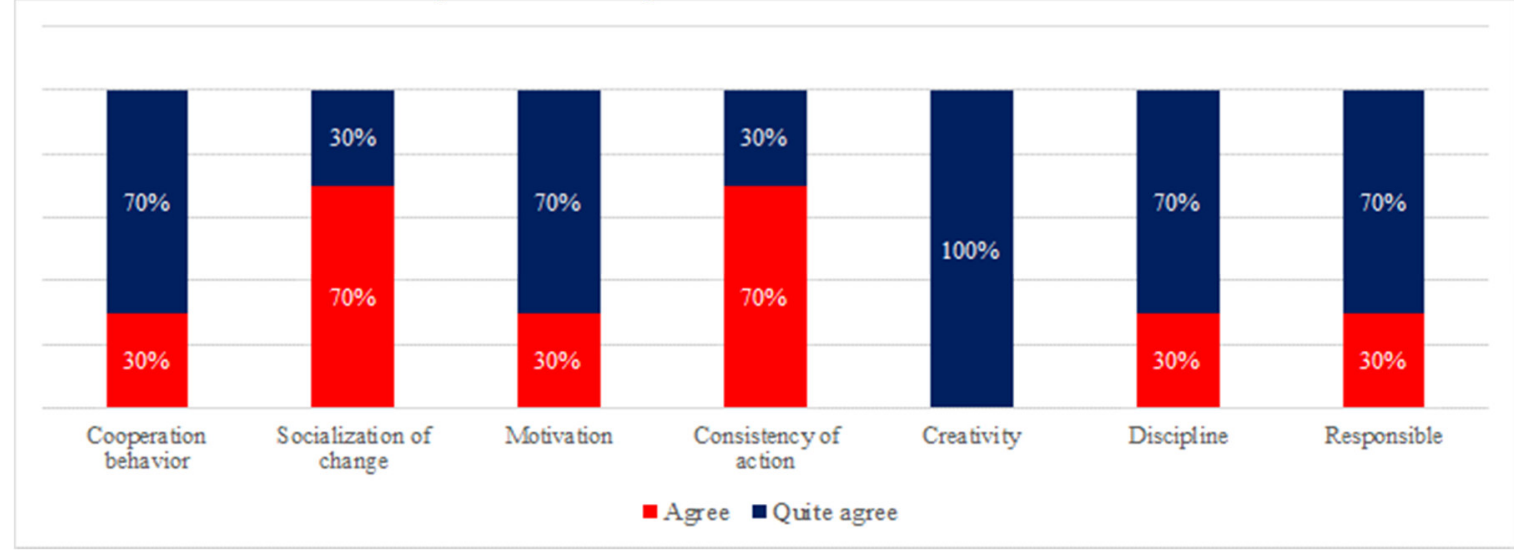

Figure 4. Evaluation of Level 3 (Behavior)

Figure 4 shows that the objectives of the training program can be achieved where participants after completing the training program state that there is a change in their behavior in working with others, they are more able to 
motivate colleagues, and they are more consistent in actions in accordance with organizational values and policies. In addition, there was an increase in the creativity, discipline and responsibility of participants in carrying out their duties.

\subsection{Level 4 Evaluation (Results)}

Good performance is performance that is consistent with organizational goals, so that performance appraisal always compares the results achieved with organizational standards (Wicaksono, 2016). The performance of participants after completing the training program is evaluated using the following indicators: increasing their skills in expressing opinions, increasing their ability to find solutions to every problem faced by individuals and organizations, increasing their ability to make positive relationships with others inside and outside organization, increasing their ability to deal with environmental changes originating from within and outside the organization, increasing their skills in working more efficiently, the benefits of applying training materials to the performance of individuals and organizations. Level 4 evaluation (results) are presented in Figure 5.

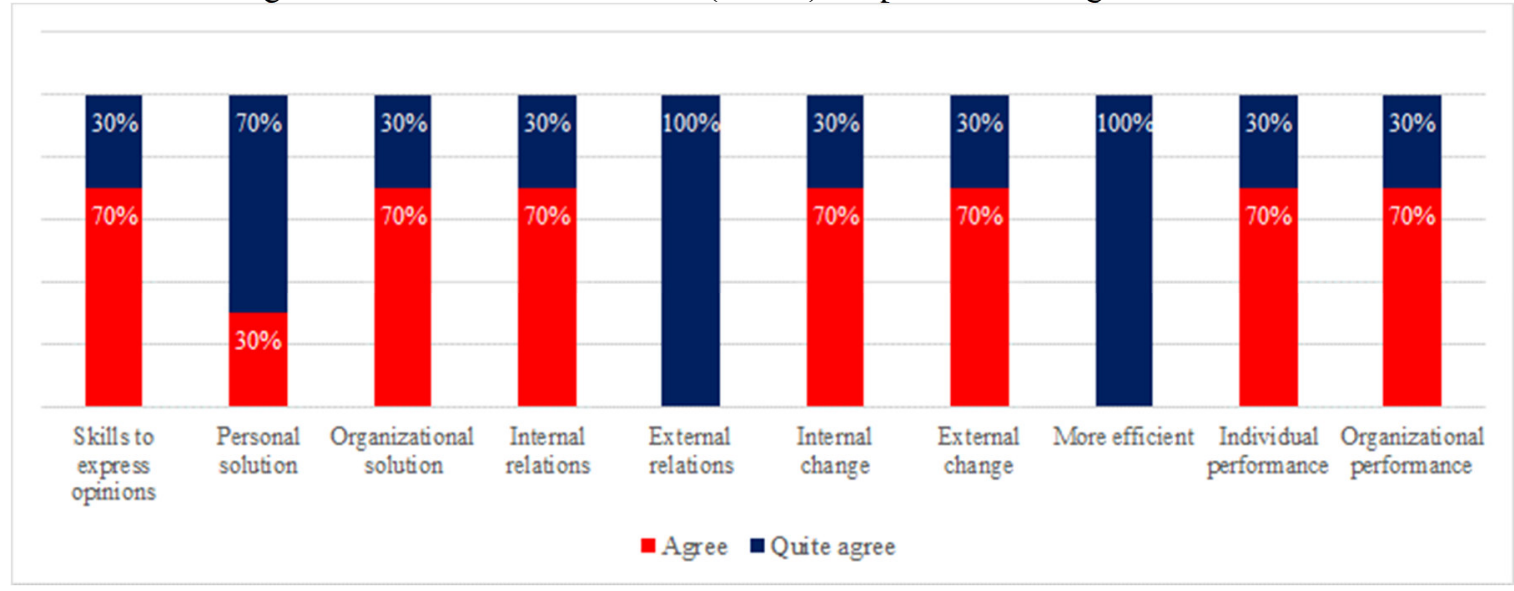

Figure 5. Evaluation of Level 4 (Results)

Figure 5 shows an increase in ability to deal with change, find solutions, and work more efficiently can improve individual and organizational performance. Increased ability to make relations can improve their organizational collaboration with other organizations and governments that can support the achievement of the vision, mission, goals and work plans of their organizations.

\section{Conclusions and Recommendations}

The CSO Manage training program can be implemented well and can achieve the objectives of the training program in the form of increasing knowledge, changing behavior and improving individual and organizational performance.

\section{Acknowledgement}

The author would like to thank the NAMA Foundation and NICE Indonesia for providing this research fund, as well as for all CSOs who were respondents in this study.

\section{References}

Al-Abbadi, L.H.M., Almomani, R.Z.Q., Abu Rumman, A.R.A.A., Abu-Rumman, A. and Khraisat, A.M.I. (2019), "Impact of Human Capital Development and Human Capital Isolation Mechanisms on Innovative Performance: Evidence from Industrial Companies in Jordan", European Journal of Business and Management, 11(15), 200-209.

Al-Nawaiseh, K.H. (2014), "The Impact of Human Resource Management Functions in Achieving Competitive Advantage Applied Study in Jordan Islamic Bank", European Journal of Business and Management, 6(38), 9-22.

Aryanti, T., Supriyono and Ishaq, M. (2015), “Evaluasi Program Pendidikan dan Pelatihan”, Jurnal Pendidikan Nonformal, 10(1), 1-13.

Farahmand, N.F. (2011), “Organizational Supporting by Human Empowerment”, European Journal of Business and Management, 3(10), 18-26.

Ferdhinawan, R.B., Susilo, H. and Ruhana, I. (2015), "Pengaruh Pelatihan Kerja Terhadap Kemampuan Kerja (Studi pada Karyawan Kantor Perwakilan Bank Indonesia Cabang Kediri)", Jurnal Administrasi Bisnis (JAB), 28(1), 71-78.

Fita, E. (2017), "Human Resource Management and Its Role in Today Organizations", European Journal of 
Business and Management, 9(11), 82-89.

Herdiansah, A.G. and Randi. (2016), "Peran Organisasi Masyarakat (ORMAS) dan Lembaga Swadaya Masyarakat (LSM) dalam Menopang Pembangunan di Indonesia”, SOSIOGLOBAL Jurnal Pemikiran dan Penelitian Sosiologi, 1(1), 49-67.

Iskandar, A. (2019), "Evaluasi Diklat ASN Model Kirkpatrick (Studi Kasus Pelatihan Effective Negotiation Skill Balai Diklat Keuangan Makassar)", Jurnal Pendidikan, 20(1), 18-39.

Okioga, C.K. (2013), "The contribution of Human Resource strategies to the Organizational Success; a case of Commercial Banks in Kisii County", European Journal of Business and Management, 5(6), 181-191.

Palupi, Y.E., Maarif, S. and Affandi, J. (2017), "Efektivitas Pelaksanaan Program Dinamika Kelompok Pada Diklat Fungsional Auditor", Jurnal Aplikasi Bisnis dan Manajemen, 3(1), 23-34.

Pirzada, D.S., Hayat, F., Ikram, A.A., Ayub, M. and Waheed, K. (2013), "Impact of Human Resources Management Practices on Turnover, Productivity and Corporate Financial Performance", European Journal of Business and Management, 5(10), 163-176.

Ritonga, R., Saepudin, A. dan Wahyudin, U. (2019), "Penerapan Model Evaluasi Kirkpatrick Empat Level dalam Mengevaluasi Program Diklat di Balai Besar Pelatihan Pertanian (BBPP) Lembang”, Jurnal Pendidikan Nonformal, 14(1), 12-21.

Saputri, Y., Purwito, L. and Widianto, E. (2019), "Pengaruh Kompetensi Fasilitator dan Hasil Belajar Peserta Pelatihan Keluarga Sehat", Jurnal Pendidikan Nonformal, 14(1), 22-36.

Shehadeh, H.K. (2015), "Role of the Human Resources Management Activities and Their Impact on Total Quality Management Requirements from the Perspective of Employees at Aramex Company in Jordan: A Case Study", European Journal of Business and Management, 7(32), 43-49.

Triasmoko, D., Mukzam, M.D. and Nurtjahjono, G.E. (2014), "Pengaruh Pelatihan Kerja Terhadap Kinerja Karyawan (Penelitian pada Karyawan PT Pos Indonesia (Persero) Cabang Kota Kediri)”, Jurnal Administrasi Bisnis (JAB), 12(1), 1-10.

Walukow, M.T., Roring, M. and Tampi, J.R.E. (2016), "Pengaruh Pelatihan Sumber Daya Manusia Terhadap Produktivitas Kerja Karyawan pada PT PLN (Persero) Wilayah Suluttenggo Area Manado", Jurnal Administrasi Bisnis, 4(4), 1-9.

Wicaksono, Y.S. (2016), "Pengaruh Pelatihan dan Pengembangan Sumber Daya Manusia Dalam Rangka Meningkatkan Semangat Kerja dan Kinerja Karyawan (Studi di SKM Unit V PT. Gudang Garam,Tbk Kediri)", Jurnal Bisnis dan Manajemen, 3(1), 31-39. 